\title{
A Retrospective Study to Determine the Type of Offence Committed by the Juveniles in the Reformatory Schools of a Capital City of India
}

\author{
Richa Choudhury ${ }^{1}$, Neeharika Mishra ${ }^{2}$, Pradeep Kumar Yadav ${ }^{3}$ \\ ${ }^{1}$ Associate Professor \& Head, Dept. of Forensic Medicine \& Toxicology, Dr RMLIMS, ${ }^{2}$ Student, MBBS IInd Year, \\ DrRMLIMS, ${ }^{3}$ Senior Resident, Dept. of Forensic Medicine \& Toxicology, DrRMLIMS
}

\begin{abstract}
Background: Juveniles of today will become the adults of tomorrow, the face of the world. Hence, it is of utmost importance to make sure that the youth of nation are given a wholesome protected environment to thrive and grow in. Aim of the Study: Our study was focussed on retrospectively studying the type of offence committed by the juveniles in the reformatory schools. Material \& Method Both male and female inmates of the reformatory schools were studied for the unlawful acts which landed them into the Reformatory schools. Observation \& Results: The percentage of boys and girls involved in non-heinous and other offences was $36.5 \%$ and $33.3 \%$ respectively; but this association of type of offence with gender was found to be statistically non-significant ( $p>0.05$ ). There were 103 cases of sexual offences, maximum Cases were of POCSO. Conclusion: Comprehensive violence prevention plans in all spheres of life, i.e. homes, schools, communities to reduce and prevent juvenile delinquency. Special programmes should be designed to prevent sexual reoffending among these juveniles. Development of facilities for counselling and psychological and psychiatric treatment as well as introduction of Juvenile mentoring programs is highly recommended in reformatory schools.
\end{abstract}

Keywords: Juvenile delinquency, Comprehensive violence prevention plans, sexual reoffending, Juvenile mentoring programs.

\section{Introduction}

Juveniles of today will become the adults of tomorrow, the face of the world. Hence, it is of utmost importance to make sure that the youth of nation are given a wholesome protected environment to thrive and grow in. As we are all aware that children come under one of the most vulnerable groups of societies which makes them more prone towards risk of many social evils. Hence it should be considered a priority to provide them with a protective environment with adequate loving care for their appropriate growth and development. ${ }^{1}$ According to many studies on adult law offenders, it has been found that they had a history of being a juvenile offender in their teenage ${ }^{2,3}$. It has been recommended that the juvenile delinquents should be given special care and there psychological and risk assessments should be done to prevent recidivism in future. ${ }^{4,5}$
The main purpose of this study is to find out violence assessment of juvenile delinquents. We also wish to address the juvenile related factors associated with violence risk. These results could be utilised by health professionals to initiate appropriate treatment either via psychotherapy or counselling for averting violence episodes and crime prevention in future.

Persons, who have not attained eighteenth year of age at the time of commission of offence, are tried as juveniles under the law. The sentences are comparatively lenient and the major focus is given to rehabilitation to make these child offenders good citizens of the future. The children and adolescents can be reformed by proper nurturing and providing the right guidance. Juvenile Delinquency in India is a major problem. Some research has been done in this sphere, to understand and effectively deal with the situation. 
Our study was focussed on retrospectively studying the type of offence committed by the juveniles in the reformatory schools. The purpose behind this study is to assess the causative factors behind the unlawful acts of juveniles and to assess the current psychological state of the juveniles.

\section{Material \& Method}

We had conducted this study on the juveniles of government Reformatory schools in the capital city of Lucknow (Rajkiya Bal Sudhar Grah boys and Rajkiya Bal Sudhar Grah, Girls,Barabanki). All the willing inmates who gave their consent for participation were included in our study. Both male and female inmates of the reformatory schools were studied for the unlawful acts which landed them into the Reformatory schools. The data collection was done in a phased manner. Permission was taken from the concerned authority, i.e. the Juvenile Justice Board Magistrate to meet and interview the juvenile inmates.

All the collected data was analysed in the form of tables and charts. The inmates were divided in two groups i.e. below 16 years of age and above 16 years of age. The type of offence committed whether nonheinous crime or a heinous crime was recorded. The number of inmates who were involved in sexual crimes was also noted separately. Presence or absence of drug abuse was also noted. The type of addiction and age of onset was asked.

\section{Observations and Results}

Table-1:Division into two groups-total 126 boys, girls 42

\begin{tabular}{|l|l|l|l|}
\hline $\begin{array}{l}\text { Serial } \\
\text { no. }\end{array}$ & $\begin{array}{l}\text { Age of } \\
\text { Juvenile }\end{array}$ & Boys & Girls \\
\hline 1 & Age $<16$ & $46(36.5 \%)$ & $7(16.7 \%)$ \\
\hline 2 & Age $>16$ & $80(63.5 \%)$ & $35(83.3 \%)$ \\
\hline & Total & 126 & 42 \\
\hline
\end{tabular}

The percentage of boys aged $<16$ years and $>16$ years was $36.5 \%$ and $63.8 \%$ respectively, and the percentage of girls aged $<16$ years and $>16$ years was $83.3 \%$ and $16.7 \%$ respectively. The percentage of boys aged $<16$ years $(36.5 \%)$ in remand home was significantly higher $(p<0.05)$ than girls aged $<16$ years $(16.7 \%)$.

[chi-square test]

Table-2:Type of Offence

\begin{tabular}{|l|l|l|l|}
\hline $\begin{array}{l}\text { Serial } \\
\text { no. }\end{array}$ & Type of offence & Boys & Girls \\
\hline 1 & Heinous offence & $\begin{array}{l}77 \\
(61.1 \%)\end{array}$ & $\begin{array}{l}28 \\
(66.7 \%)\end{array}$ \\
\hline 2 & $\begin{array}{l}\text { Non heinous } \\
\text { offence* }\end{array}$ & $\begin{array}{l}48 \\
(38.1 \%)\end{array}$ & $\begin{array}{l}14 \\
(33.4 \%)\end{array}$ \\
\hline 3 & Others* & $\begin{array}{l}1 \\
(0.8 \%)\end{array}$ & $\begin{array}{l}0 \\
(0 \%)\end{array}$ \\
\hline & Total & $\begin{array}{l}126 \\
(100 \%)\end{array}$ & $\begin{array}{l}42 \\
(100 \%)\end{array}$ \\
\hline
\end{tabular}

* These groups were merged for statistical purpose.

The percentage of boys and girls involved in nonheinous and other offences was $36.5 \%$ and $33.3 \%$ respectively; but this association of type of offence with gender was found to be statistically non-significant $(\mathrm{p}>0.05)$.

[chi-square test]

Table-3: Sexual offence

\begin{tabular}{|l|l|l|}
\hline $\begin{array}{l}\text { Serial } \\
\text { no. }\end{array}$ & Sexual offence & Cases \\
\hline 1 & POCSO Act & 48 \\
\hline 2 & 376 IPC & 43 \\
\hline 3 & 354 IPC & 12 \\
\hline & Total & 103 \\
\hline
\end{tabular}




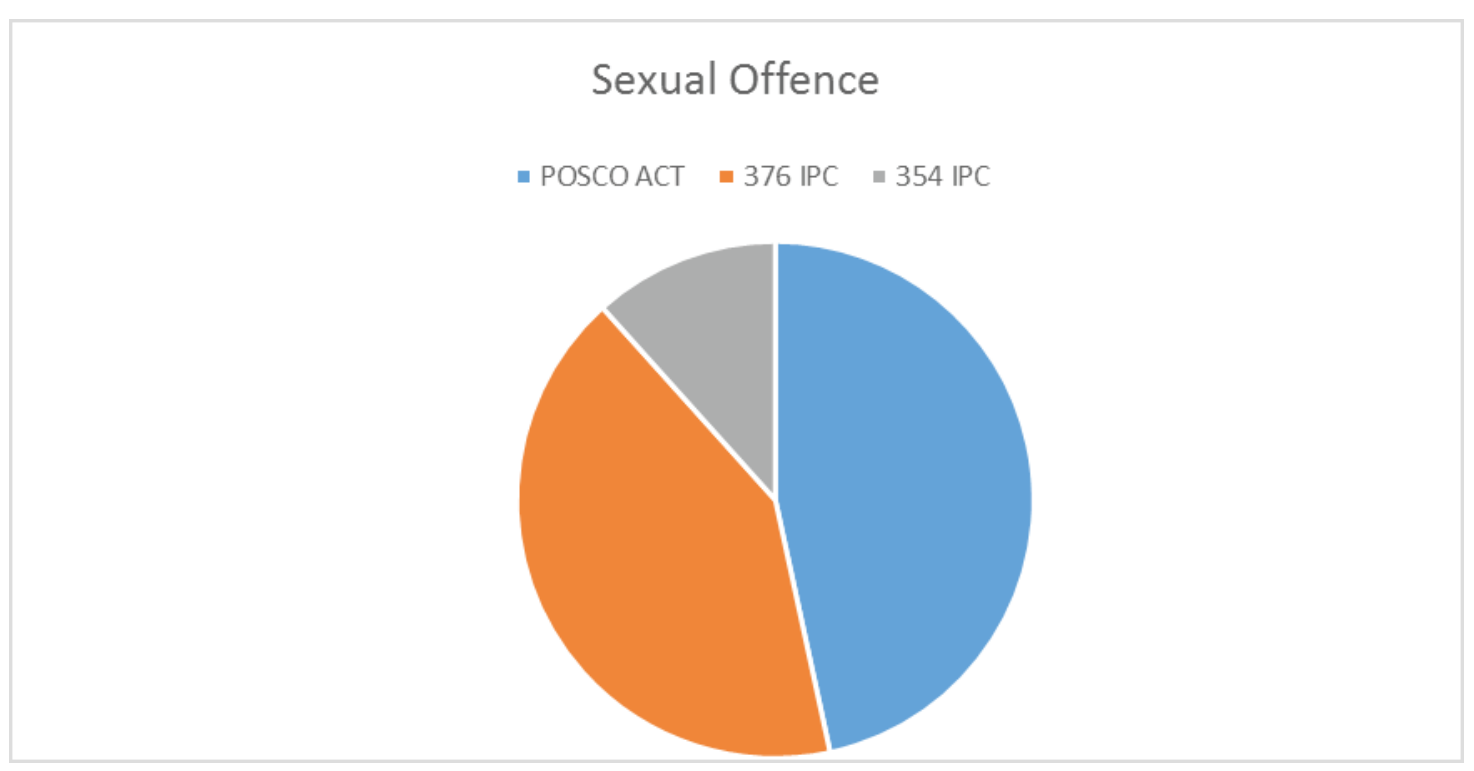

\section{Discussion}

Our study reveals that the major part of the population of juvenile offenders in remand homes belong to the age group of older than sixteen $(63.49 \%)$. This finding is significant as it may point towards the increasing tendency of older adolescents to commit crimes. The reasons may vary. Increased testosterone levels in this age group may contribute greatly to the tendency to commit violent and sexual crimes. Greater levels of testosterone have been linked to aggression by various studies. ${ }^{6,7,8,9}$ Dominating behaviour may also be a result high testosterone. ${ }^{10,11}$ The greater rate of crimes in this age group may also be due to association with adult criminals.

$73.57 \%$ of the female inmates are older than 16 . Some of the girls were even eighteen years old and one of them was twenty-one. These findings indicate the same trend of increasing rates of crimes in older adolescents. It was also observed that the age group of older adolescents committed more violent and heinous crimes than the younger population, including murder and assault. The rising aggression in older females could be due to hormonal changes. The younger population in general committed relatively minor crimes like theft and fraud.

The juveniles belonging to more affluent sections have mostly been arrested under the charges of rape. Many of them were in consensual relationships. This is a very typical scenario in the present age where advantage of existing archaic laws is taken for personal revenge.
Despite engaging in sexual activities with full consent, the boy was found guilty of rape as the legal age for consent is 18. Perhaps it is indeed time to review and change the legal age of consent. The ages of attaining puberty in general have been declining indicating earlier onset of puberty. ${ }^{12,13,14,15}$ In addition, trends of increasing age of marriage and westernization and liberalization of attitudes towards sexual relationships lead to greater number of teenage relationships. The dynamic, changing attitudes of the society must be contemplated and laws be amended.

A whopping $61.11 \%$ of the male juveniles and $66.67 \%$ of female adolescents have committed heinous crimes, which are crimes so grave that they have to be tried in courts as adults. These include rape, murder etc. This disturbing observation raises various questions. What causes children and adolescents to commit such grave crimes? Can this be predicted or prevented? 10\% of boys were booked under the POCSO Act and 34.13\% under IPC 376, rape. The alarmingly high number of sexual offenses including child rape may be because of increasing sexualization of youths in films and media, easy access to pornographic material and repression of sexuality in the Indian culture. Hormonal levels may also be at blame as studies have linked violent sexual crimes and repeated sexual offences to high levels of testosterone ${ }^{16}$. In the rural settings, penetration of internet and quick, effortless access to pornographic films and violent videogames may be at blame. Sex is considered a taboo and society refuses to discuss it, but it 
needs to be openly talked about to create awareness and propagate information. Lack of sensitization towards the opposite gender may also be at blame. The current trends regarding violent sexual crimes are discerning. Various studies provide solid evidence suggesting increase in chances of violence and aggression amongst youngsters due to violence in media. This may be due to the tendency of youngsters to emulate observed behaviour. The research by Anderson et al emphasises the link between media and violence. ${ }^{17}$

An extremely disturbing trend observed was the massive number of female juveniles convicted for murder. $45.25 \%$ of the girls had committed murder. The reasons for this finding are not properly understood. This must be delved into and studied deeply by further research. Some girls may get involved in romantic relationships and try to elope. When objected by parents and other people they may commit murder due to anger and frustration. Many female inmates have been arrested under Dowry Prevention Act, Section 498 IPC for cruelty to wife by husband or relatives and Section 304 B for dowry death. The girls arrested under Section 498 are mostly sister in laws that get entangled in the family altercations.

Some inmates showed recidivism, they were arrested many times for various offences. These individuals must be given special attention and the underlying causes should be assessed. Upon offering proper guidance, we can come a long way in preventing future crimes. By providing education and vocational courses, social support and rehab facilities, we can effectively reduce the recidivism rates. The stigma attached to convicts need to be eliminated to ensure their assimilation into the mainstream society and rehabilitation.

An important aspect to be looked into is the mental health of the juveniles. It is difficult for these teenagers to stay away from their families and homes. The lack of familial support at this crucial time is very difficult for the juveniles. The contribution of family in the mental health of juveniles cannot be overlooked.18 The Company of other convicted adolescents especially for violent and aggressive crimes, may not be very welcoming. A strong supportive network is extremely essential for maintaining good mental health. The remand homes must strive to provide a nurturing and fear free environment for growth and wholesome development of the juveniles.

\section{Conclusion}

We suggest appropriate measures should be taken to prevent youth victimization and violence, which should include comprehensive violence prevention plans in all spheres of life, i.e. homes, schools, communities. This will definitively reduce as well as prevent juvenile delinquency. Special programmes should be designed to prevent sexual reoffending among these juveniles. They should be provided with appropriate counselling and psychotherapy as and when needed at regular intervals. Such type of intervention could play a major role in preventing recidivism. Extra emphasis should be given to address the needs of the girls in the juvenile reformatory homes. The focus should be on developing new community based and culturally responsive alternatives for reducing too much dependence on confinement of these juveniles in the remand homes.

Development of facilities for counselling and psychological and psychiatric treatment is highly recommended in reformatory schools. Juvenile mentoring programs should be initiated in the reformatory schools where the mentors should guide the juveniles and provide technical assistance and training in their field of interest. There should be facility for web based free learning and training. Thus, we can expect that through proper care and counselling, these juveniles including those showing predisposition towards violence could be moulded to grow in the right direction and become good and responsible citizens of our nation.

\section{Ethical Clearance -Taken}

Time line-The total duration of the study was six months

\section{Budget-Nil}

\section{Conflict of Interest-None}

Acknowledgement- We're extremely thankful to the Superintendents of Reformatory schools for their support and cooperation in this research work

\section{References}

1. Barnum R. An agenda for quality improvement in forensic mental health consultation. Bulletin of the American Academy of Psychiatry and the Law. 1993; 21: 5-21.

2. Bow JN, Quinnell FA. Psychologists' current practices and procedures in child custody 
evaluations: five years after American Psychological Association guidelines. Prof Psychol. 2001; 32: $261-8$.

3. Grisso T. Forensic evaluation of juvenile offenders: A manual for practice. Sarasota, FL: Professional Resource Press.1998.

4. Ewig C.P. Juveniles or adults. Forensic assessment of juveniles considered for trial in criminal court. Forensic reports.1990;3: 3-13.

5. Fegan JA. The comparative advantage of juvenile versus criminal court sanctions on the recidivism among adolescent felony offenders. Law and policy. 1996; 18: 77-113.

6. Alami A, Shahghasemi Z, Davarinia Motlagh Ghochan A, Baratpour F. Students' Aggression and Its Relevance to Personal, Family, and Social Factors. Iran Red Crescent Med J. 2015;17(12):e20017. Published 2015 Dec 5. doi:10.5812/ircmj.20017

7. Archer J. Testosterone and human aggression: an evaluation of the challenge hypothesis. NeurosciBiobehav Rev. 2006;30(3):319-45. doi: 10.1016/j.neubiorev.2004.12.007.

8. Carre JM, McCormick CM, Hariri AR. The social neuroendocrinology of human aggression. Psychoneuroendocrinology. 2011;36(7):935-44. doi: 10.1016/j.psyneuen.2011.02.001.

9. Kreuz LE, Rose RM. Assessment of aggressive behavior and plasma testosterone in a young criminal population. Psychosom Med. 1972;34(4):321-32.

10. Chichinadze KN, Domianidze TR, Matitaishvili T, Chichinadze NK, Lazarashvili AG. Possible relation of plasma testosterone level to aggressive behavior of male prisoners. Bull Exp Biol Med. 2010;149(1):7-9. doi: 10.1007/s10517-0100861-z.

11. Ehrenkranz J, Bliss E, Sheard MH. Plasma testosterone: correlation with aggressive behavior and social dominance in man. Psychosom Med. 1974;36(6):469-75

12. van Bokhoven I, van Goozen SH, van Engeland H, Schaal B, Arseneault L, Seguin JR, et al. Salivary testosterone and aggression, delinquency, and social dominance in a population-based longitudinal study of adolescent males. HormBehav. 2006;50(1):11825. doi: 10.1016/j.yhbeh.2006.02.002.

13. Bradford JM, McLean D. Sexual offenders, violence and testosterone: a clinical studyCan J Psychiatry. 1984 Jun;29(4):335-43.

14. O'Connor DB, Archer J, Hair WM, Wu FC. Exogenous testosterone, aggression, and mood in eugonadal and hypogonadal men. Physiol Behav. 2002;75(4):557-66. doi: 10.1016/S00319384(02)00647

15. Aluja A, Torrubia R. Hostility-aggressiveness, sensation seeking, and sex hormones in men: reexploring their relationship, Neuropsychobiology, 2004;50(1):102-7. doi: 10.1159/000077947.

16. Dabbs JM Jr, Hargrove MF Age, testosterone, and behaviour among female prison inmates. Psychosom Med. 1997 Sep-Oct;59(5):477-80.

17. Pare PP, Felson R. Income inequality, poverty and crime across nations.Br J Sociol. 2014 Sep;65(3):434-58. doi: 10.1111/1468-4446.12083. 